\title{
The Value of Information Systems Teaching and Research in the Knowledge Society
}

\author{
Christopher J. Hemingway \\ Information Systems Research Centre, \\ Cranfield School of Management
}

c.j.hemingway@cranfield.ac.uk

\author{
Tom G. Gough \\ School of Computing, \\ University of Leeds
}

gg@comp.leeds.ac.uk

\begin{abstract}
Governments and businesses are becoming ever more interested in the production and capitalisation of knowledge, so much so that the 'knowledge economy' is now regarded as the paradigm of economic progress. This has significant implications for teaching and research generally, and for the IS community in particular. This paper provides a brief analysis of general developments in higher education to provide a context for discussing the developments specific to IS. Stakeholder analysis is then used to identify the main responsibilities and pressures placed upon the IS academic community. Using the stakeholder analysis as a set of 'requirements' that the IS academic community must balance, several ways in which IS teaching and research can better contribute value to the various stakeholder groups are identified. Throughout the paper, several 'policy level' recommendations are made that could lead to the IS community being better able to manage the pressures exerted by different stakeholder groups and, consequently, being more able to address a broad range of commercial and social issues.
\end{abstract}

Keywords: Industry-university collaboration, IS Education, IS Research, Knowledge society, Policy, Stakeholder analysis

\section{Introduction}

Increasingly, businesses in developed nations are facing greater competitive pressure because efficient production is now the norm in many industries. Consequently, new ways of establishing comparative advantage are being sought. Increasingly, businesses are seeking to create competitive advantage by reconfiguring their activities so that they are better aligned with ever-changing market needs. This model of market competitiveness relies upon the rapid exploitation of business intelligence, which requires workers to possess information handling and decision making skills. The 'knowledge economy' is now regarded as the paradigm of economic progress. Moreover, it is envisaged that reforms to educational and social policies will create a 'knowledge society' conducive to such economic change.

In the public sector, some governments are mandating the use of Internet technologies to achieve cost reductions. Effectively, the policy goal is to reduce the size and cost of existing

Material published as part of this journal, either on-line or in print, is copyrighted by the publisher of Informing Science. Permission to make digital or paper copy of part or all of these works for personal or classroom use is granted without fee provided that the copies are not made or distributed for profit or commercial advantage AND that copies 1) bear this notice in full and 2) give the full citation on the first page. It is permissible to abstract these works so long as credit is given. To copy in all other cases or to republish or to post on a server or to redistribute to lists requires specific permission and payment of a fee. Contact Editor@inform.nu to request redistribution permission. bureaucracies by making them self-service. Although the focus is on efficiency, the societal implications are similar to those of the private sector: citizens will be disadvantaged if they lack information handling and decision making skills. Considering this broad socio-economic picture, the role of IS education in universities can be considered at three distinct levels: (a) citizen/society (Vinten, 2000); knowledge worker (Cardinali, 1998); and IS/knowledge expert (Doke and Williams, 1999). Whilst university education in IS may rightly focus on the third level, it must address the wider context, including the role of IS experts in educating/training knowledge workers and citizens, in solving their problems and satisfying their information needs.

The increase in demand for 'knowledge skills' has created, and been influenced by, marked changes in educational requirements. Over the past few decades, this has led to the massification of higher education, which is providing a broader base of intellectual skills in most advanced economies. This not only affects higher education teaching but also has major implications for university research, in general, and IS research, in particular. As society becomes a mass of competent and discerning knowledge users, the user base for academic research broadens and its demands change. Other organisations also establish themselves as knowledge producers that complement or compete with universities.

Governments concerned with economic performance have also maintained policies of encouraging universities to pro- 
duce knowledge of clear economic value and to participate in its capitalisation (Etzkowitz et al., 2000).

This paper argues that the role of IS teaching and research in universities needs to be reconsidered in the light of the complex of social, political and economic change outlined above. The kinds of knowledge being produced, the target stakeholders and the nature and extent of competition and collaboration between IS knowledge producers needs to be reevaluated. The radical changes in the societal role of the university must be appreciated and their implications for singular disciplines, such as information systems, understood. Section 2 , therefore, provides a brief overview of the traditional role of the university and how this is changing as the knowledge society paradigm influences the direction of social and economic change. During this discussion, a number of stakeholder groups are identified. The needs and expectations of these stakeholders are considered in section 3 to provide a broad view of the requirements of the IS discipline. Using this analysis, the teaching and research roles of IS academics are considered in section 4 and some 'policy level' recommendations for the IS academic community are made. Section 5 concludes the paper by reflecting upon the implications of this analysis for the IS discipline's relationships with the identified stakeholder groups.

\section{Academia in the Knowledge Society}

Until quite recently, the university was regarded as a producer of 'pure' knowledge. This conception has evolved as debates about the status of scientific knowledge have progressed. It is, perhaps, for this reason that European universities in the late $19^{\text {th }}$ and early $20^{\text {th }}$ centuries began to recognise engineering and other applied subjects as valid areas of academic enquiry (Neave, 2000). Despite the changing perceptions of the epistemological role of the university, its social role as a 'disinterested observer' sensitive to the interests and concerns of all members of society continued to be maintained. Following the Second World War, however, universities came to be increasingly regarded as valuable sources of intellectual capital and, from the 1960s onwards, the higher education sector was dramatically expanded in many industrialised nations. The massification of higher education and the capitalisation of knowledge are two of the distinguishing characteristics of the 'knowledge society' paradigm.

Of the two key changes characteristic of the knowledge society, massification has been the most rapid and most visible development. From some perspectives, the increase in student numbers has been beneficial. Most notable among these is the opening-up of higher education to students from a wider range of social backgrounds. This is not to say, however, that more students now have the same academic experiences as were previously provided to a more exclusive group of students. The increase in the scale of university teaching has led to institutional changes that have produced a qualitative shift in the nature of university education (Gumport, 2000). Firstly, the sheer growth in class sizes has inevitably led to changes in teaching styles. Lectures to hundreds of students are more one-sided than those delivered to tens of students, and the substitution of individual and small group tutorials with more 'efficient' teaching methods further emphasises one-way communication from the academic staff to the students. Consequently, there has been a shift from 'education as intellectual dialogue' to 'education as knowledge delivery.' Moreover, this delivery is often regarded in terms of economic value (Neave, 2000). At present, the greatest extension of the knowledge delivery orientation is the notion of computerbased distance learning.

Looking beyond the university itself, the rapid growth in the number of graduates has altered perceptions of the university and, consequently, changed the context in which university performance is assessed. Where, in some countries, university was once regarded as preparation for prestigious roles in the civil service and the larger corporations, it has increasingly become a requirement for all professional posts, including relatively junior posts in industry. This, combined with the increasing numbers of graduates who, because of their social background, have a financial need to secure employment after graduation, leads to higher education being regarded less as the socialisation of an elite and more as a form of vocational training. Consequently, employers and students are increasingly vocal in their demands for commercially relevant degree programmes and their desire for interpersonal skills. It is interesting to note that development of interpersonal skills is often expressed in terms of well-rounded individuals but can equate in practice to the socialisation of students according to a business ethic, prior to their employment in industry.

Just as graduates have lost their elite status as a consequence of the massification of higher education (Enders, 1999), so universities have also lost prestige. As more graduates work in the economy, so industry becomes increasingly capable of satisfying its own knowledge requirements and the knowledge requirements of others. Of course, the ideals and objectives driving knowledge-based businesses differ from those of a traditional university. At the societal level, such diversity leads to the evaluation of knowledge producers according to a wider range of criteria. Universities may be valued for their greater impartiality, for example, but will remain open to comparison with other knowledge producers in terms of their cost efficiency and economic value. 
Although examples can be found in the $19^{\text {th }}$ century at Harvard University and MIT, the capitalisation of research has only become widespread over the past twenty years (Etzkowitz, 1998). This makes it a more recent phenomenon than massification and, as yet, it is also a less substantial one. Nevertheless, the changes are significant and may have a major impact on the nature of universities over the long-term, blurring the distinction between university and industry activity.

There are two main drivers of the capitalisation of university knowledge production. First, the rapid expansion of university research has led to the demand for public research funding exceeding its supply (Etzkowitz, 1998; Mitchell, 1999). Second, scientific advance is increasingly reliant upon the use of technological advances, whilst technological innovation depends more upon progress in particular areas of research (Etzkowitz 1998). Thus, research and technological development have become tightly coupled and universities and firms, consequently, have become interdependent. This interdependence has led to the evolution of both academia's and industry's institutional arrangements and values (Carayannis et al., 2000). Some university research is increasingly conducted according to industrial goals and working practices (Etzkowitz 1998). In industry, many organisations are changing in an attempt to improve their learning and knowledge production capabilities, as evidenced by the increased interest in knowledge management technologies (Eppler and Sukowski, 2000).

There exists now in many universities a spectrum of 'business models' for research activity. At one extreme, some academics fund their research entirely by winning government grants. At the other extreme, some researchers form spin-off companies to profit from their own research. In between, commercial funding can be gained in return for varying degrees of influence over the research programme and privileged access to research findings. From an academic perspective, capitalisation can have both positive and negative impacts. Capitalising upon research can potentially lead to research findings (some of which are publicly funded) becoming the private knowledge of companies (Polster, 2000). On the other hand, some spin-off companies have charged businesses for software to help fund the provision of free research tools to universities (Etzkowitz, 1998). The income from business sales funds the technical support and maintenance of the software. Thus, it can be argued that some models of capitalisation may inhibit knowledge production and dissemination, whilst other models support it.

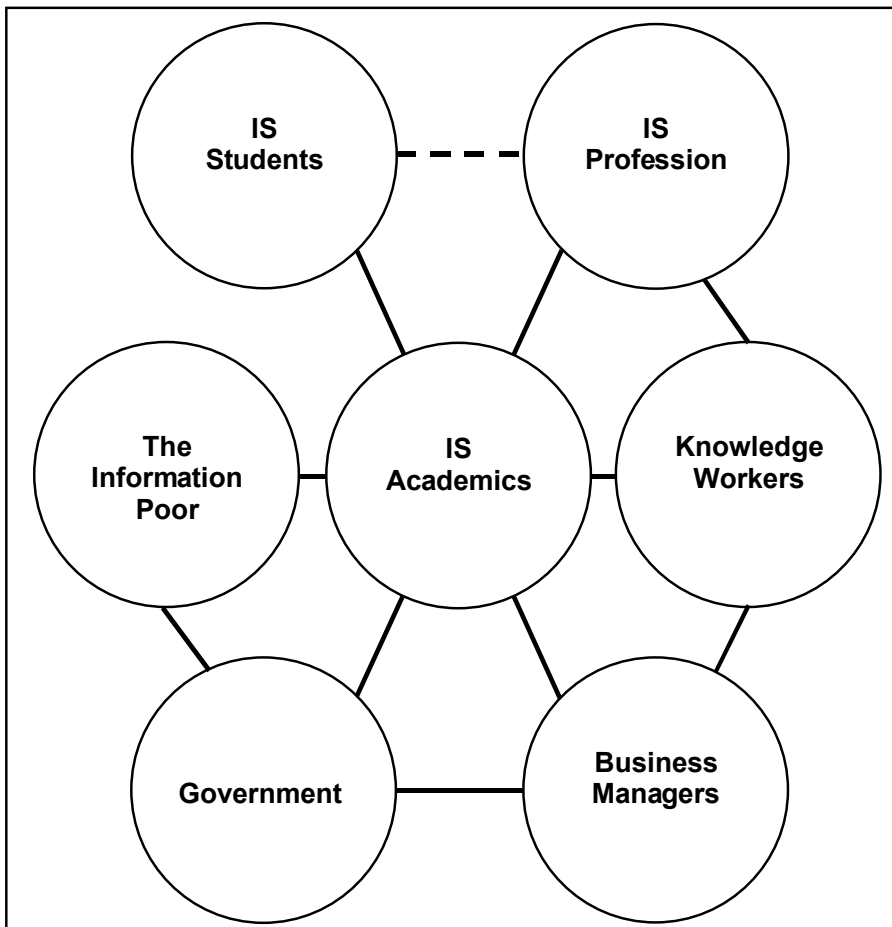

Figure 1: Stakeholder groups to be considered in the analysis of IS teaching and research

\section{The Information Systems Discipline's Key Stakeholders}

The IS academic community interacts with a number of stakeholder groups. In this section, the needs, demands and responsibilities of seven key groups (Figure 1) are briefly examined.

\section{Information Systems Students}

The contribution that higher education can make to a student can be broadly described in terms of education, training and socialisation (Teichler, 1999). As already noted, the massification of higher education has led to changes in the social profile of the student body and altered the balance of these three factors. Prior to massification, university education was regarded as a way of socialising an established elite, as well as sharpening the critical and analytical skills of students. Moreover, as most students would enter the civil service or adopt management roles in large corporations, the development of social, rather than technical, skills was regarded as valuable preparation for a career. Financial pressures were typically limited for students because those attending university had families that could readily provide financial support.

Following the massification of higher education, the social profile of the student body has considerably broadened. Stu- 
dents in the UK initially received considerable financial support, enabling students from poorer backgrounds to receive higher education. The continued expansion of higher education, however, has required students and their families to bear an increasing financial burden. One consequence of this shift is that both the cost of education and the financial rewards following graduation are now prominent variables affecting students' decisions. In order to reduce the cost of university education, students in the UK are recommended to study closer to the family home (Sheridan, 2000). Some recent graduates are also returning to the parental home because they cannot afford to service their student debts and pay for their own accommodation (Freeman, 2000). To increase financial benefits, students have become increasingly aware of the graduate recruitment market. Decisions about university education are now influenced by considerations of graduate starting salaries, the marketability of skills and employers' offers of 'golden hellos' to pay off student debts. The increasing numbers of degrees with vocational labels, such as Information Systems, serves to reinforce the association between skills gained at university and earning prospects. These pressures increase at postgraduate level, where students often choose to do an MSc or MBA in Information Systems to gain technical or managerial skills required for promotion. The need for skills to differentiate graduates in the job market may explain why particular skills seem to be preferred over general critical and analytical skills and why students want to use the latest hardware and software when studying IS. In effect, this represents a shift from education to training as a priority in IS and other vocational/technical disciplines.

Massification has also had a direct effect on the kinds of education and socialisation provided to, and expected by, students. Higher education is regarded less as a privilege (Enders, 1999) and less as reinforcing privileged social positions. Teaching methods have also changed to accommodate the changing staff-student ratio. There has been a general shift away from intellectual dialogue within small groups and towards knowledge delivery in which staff-student (and often student-student) interaction is limited. This shift can be accentuated by programmes that require the extensive use of computers for developing and using software, particularly those that rely upon independent work. Changes to the social interaction component of undergraduate and Masters level education is reflected in the growing significance of nightlife and society membership as social functions of universities. The degree programme can increasingly be regarded as a series of intellectual episodes in which social interaction is perfunctory. The ability to deliver distance learning programmes illustrates the reduced significance of networks of social interaction as vehicles for learning and skills development.

\section{IS Professionals}

IS professionals influence students and higher education institutions in two main ways:

(a) they manage the balance of IS skills in the organisation and articulate skills requirements; and

(b) they interpret and manage industry's demands of IS professionals.

As employers, IS professionals play a major role in setting the expectations of IS students by articulating their requirements. Typically, job advertisements suggest that companies need graduates with the latest technical skills, giving students the impression that the ability to use emerging technologies is most highly valued. The emphasis on requiring and providing up-to-date skills has been exacerbated by the shortage of IS skills and the tendency of employers to focus on short-term needs (Teichler, 1999) rather than on the full range of skills that they require. The difficulty in communicating the need for general analytical and critical skills in a job advert also leads to an emphasis on the particular and the technical. This bias in the reporting of industry's requirements of IS graduates potentially disadvantages both employers and students.

Most IS functions require a combination of skills to maintain existing systems and to develop new solutions. Of the new solutions developed, some will use established, rather than leading edge, technologies. Thus, the use of established technologies is likely to be a component of many jobs filled by IS graduates. The graduate recruitment literature, however, places very little emphasis on such skills. This disparity suggests that a substantial number of students will typically apply for posts advertised as requiring cutting edge skills and providing opportunities for learning new technologies as they emerge. Nevertheless, a substantial number of these students will be expected to work using older technologies and much of their training may involve learning to use older technologies rather than cutting edge skills. Many of the new technologies learned during university study and in the student's own time may not be used in practice.

From the perspective of the employer, advertising for skills that do not balance with actual requirements can disadvantage the IS function but is, nonetheless, required both to attract graduates and to convey (within and without the organisation) a forward-looking, hi-tech image. In terms of satisfying the IS function's customers, however, the recruitment of such individuals may be limiting. Attempting to retain a balance at the selection stage is difficult because the generic skills required of IS professionals are difficult to assess apart from knowledge of particular skills. An applicant may, for example, know less about database design but have used the latest database 
technologies. Such a student may outshine an applicant with extensive knowledge of database design in a selection process, despite his/her ability to learn about new technologies very rapidly. An IS manager may be inclined to employ the first applicant simply because customers are asking about the new database technology, despite it being likely that the student will develop information systems of lower quality, shorter lifetime and with higher maintenance costs.

In addition to managing the skills available within an IS function, IS managers must also manage the demands placed upon the IS function and develop the skills base accordingly. As illustrated by the progression from centralised data processing departments to end-user computing and now to e-commerce, the IS function has a growing number of customers/users to serve. As new types of users emerge and their requirements and levels of sophistication develop, the skills required of the IS function must adapt. Over the short-term, one solution is to seek those skills in graduate employees. Over the longer-term, the IS profession would benefit from influencing the development of education and training. Unfortunately, the mechanism by which professions typically influence education, such as accreditation by professional bodies and a clear career structure, have little influence in IS. Whereas IS employers have reviewed IS curricula voluntarily, other professions, such as medicine and engineering, practically determine what university curricula will contain. IS job titles also vary dramatically between organisations and often do not reflect the activities of the person holding the post. Furthermore, accreditation is essential for employment in many professions but is little more than a 'nice to have' for most IS professionals.

Despite the lack of professionalisation and institutionalisation of IS, the need for standards of professional conduct is set to grow dramatically. The level of investment in IT is increasing, the number of failures is significant and IS projects increasingly underpin key operational and strategic activities in organisations. Consequently, a mistake or incompetent action on the part of an IS professional can increasingly have consequences as severe or worse than in the medical, legal or engineering professions (an action by an IS professional working for an application service provider, for example, could potentially have catastrophic effects on hundreds of companies). The pervasiveness of IT in society also raises many ethical issues for IS professionals. When managing software projects, for example, IS professionals should consider potential violations of trust, professional adequacy, fairness with regard to all stakeholders, and a range of other issues (Rogerson and Gotterbarn, 1998). Dealing with such issues is typically addressed through the requirements of professional institutions, which have committees capable of imposing sanctions for professional misconduct and are some- times able to prevent professionals from practising. IS has no such institutional arrangements by which to maintain standards within the profession. For the IS manager, the absence of professional requirements provides the freedom to employ graduates from other disciplines and to provide them with only the training necessary for performing work tasks; a freedom that is highly valued given the current IT skills shortage. On the negative side, the IS profession is unable to exert significant influence over education and training of professionals and, consequently, faces considerable uncertainty regarding the knowledge and competencies of the graduates (and professionals) employed.

\section{Knowledge Workers}

As noted above, the 'customers' of the IS professional have changed. Initially, data processing services were provided to data users who had no computing experience. End-user computing radically altered this, introducing IT support into the repertoire of the IS professional. The IS professional, at this stage, was required to solve technical problems and communicate with (and sometimes train) non-technical computer users. The increasing use of IT to support business activities and the use of the Internet to communicate with customers is again leading to a major shift in the demands placed upon the IS professional.

Increasingly, workers in many business sectors are coming to rely upon the provision of information through formal information systems in performing their jobs. It is this reliance on formal information systems that characterises knowledge work, reflecting the significant impact of IS and IT on business activity (note that this broad definition includes, for example, call centre workers, rather than restricting the term 'knowledge worker' to highly skilled information handling experts, such as researchers). Relying on information systems has an important consequence for business: relationships with customers are directly affected by the quality and reliability of these systems and their component technologies. As the dependencies on formal IS increase, so the ability of the knowledge worker to mitigate problems with data quality and availability is likely to decline. Furthermore, it is becoming increasingly common with the adoption of e-commerce to provide customers with direct access to an organisation's information systems. The impacts on knowledge workers and IT professionals are summarised in Table 1.

For the knowledge worker, the move to Internet technologies is likely to have the following impacts on working practices:

- Problems with IS and/or data quality will be apparent to customers. Consequently, difficulties and mistakes must 


\begin{tabular}{|l|l|l|l|}
\hline & $\begin{array}{l}\text { IS } \\
\text { Professional }\end{array}$ & $\begin{array}{l}\text { Knowledge } \\
\text { Worker }\end{array}$ & Customer \\
\hline $\begin{array}{l}\text { Data } \\
\text { Processing }\end{array}$ & $\begin{array}{l}\text { Technical } \\
\text { expertise } \\
\text { required to } \\
\text { ensure data is } \\
\text { processed } \\
\text { efficiently and } \\
\text { reports } \\
\text { generated in a } \\
\text { timely manner. }\end{array}$ & $\begin{array}{l}\text { Provide raw } \\
\text { data on } \\
\text { business } \\
\text { transactions } \\
\text { and } \\
\text { request/utilise } \\
\text { reports from DP } \\
\text { department. }\end{array}$ & $\begin{array}{l}\text { Engage in } \\
\text { manual } \\
\text { transactions } \\
\text { with } \\
\text { organisation. }\end{array}$ \\
\hline $\begin{array}{l}\text { End-User } \\
\text { Computing }\end{array}$ & $\begin{array}{l}\text { Provide } \\
\text { technical } \\
\text { support and } \\
\text { training to non- } \\
\text { technical users. }\end{array}$ & $\begin{array}{l}\text { Use IT to } \\
\text { support } \\
\text { interaction with } \\
\text { customers. }\end{array}$ & $\begin{array}{l}\text { Engage in } \\
\text { transactions } \\
\text { with knowledge } \\
\text { workers who } \\
\text { have computer } \\
\text { support. }\end{array}$ \\
\hline $\begin{array}{l}\text { Internet/ } \\
\text { E-Commerce }\end{array}$ & $\begin{array}{l}\text { Support } \\
\text { knowledge } \\
\text { workers and } \\
\text { provide IT } \\
\text { services to the } \\
\text { business's } \\
\text { customers. }\end{array}$ & $\begin{array}{l}\text { Front-line } \\
\text { support for } \\
\text { customers who } \\
\text { have technical } \\
\text { and/or } \\
\text { transaction- } \\
\text { related } \\
\text { problems. }\end{array}$ & $\begin{array}{l}\text { Use IT to } \\
\text { perform some } \\
\text { transactions. } \\
\text { Other } \\
\text { transactions } \\
\text { with knowledge } \\
\text { workers who } \\
\text { have computer } \\
\text { support. }\end{array}$ \\
\hline
\end{tabular}

Table 1 - The Impacts of Information Technologies on Experts and Users

be acknowledged and then dealt with effectively and to the satisfaction of the customer.

- Decisions about customers must be consistent with data in the formal information system, which customers can now access.

- In addition to dealing with customers' transactions, knowledge workers will be expected to deal with technical issues relating to the systems accessible to customers.

For the IS professional, these changes in knowledge work are likely to have the following impacts:

- As knowledge workers become more technically competent users of information systems and handle basic technical queries from customers, IS professionals will be asked to deal with a wider range of more difficult problems. As reliance on systems increases, however, there will be an increased expectation that IS professionals will answer questions and solve problems more quickly and effectively.

- IS professionals will be required to interact with a wider range of stakeholders, ranging from senior managers in supplier and partner organisations through to individual customers. Consequently, the IS professional will require negotiation, management and interpersonal skills as well as being technically competent and understanding key business activities.

Significant changes in the relationship between knowledge worker and IS professional are also likely to occur. For the knowledge worker, IT-based systems define key work activities. Consequently, a persistent threat is that developments in IT will lead to work activities being completely automated. Alternatively, business managers may identify some knowledge-based activities as targets for outsourcing to large, specialist service providers. To manage these options and to maintain the value of knowledge workers, businesses are increasingly recognising the value of particular skills rather than the seniority of employees. Consequently, knowledge workers are under constant pressure to keep their skills and knowledge updated. These changing management practices require the IS professional not only to get closer to the knowledge worker as a 'customer' but also to take part in reshaping (and sometimes eliminating) the knowledge worker's role. This may involve working on a team negotiating an outsourcing agreement or contributing IS development skills to an organisational change programme. Such activities must be undertaken whilst maintaining a viable working relationship with the knowledge workers who are influenced by this change. It seems likely, therefore, that the job design and change management capabilities first identified in the 1960s (see, for example, Mumford and Ward, 1968) will become increasingly important for the IS professional who must deal with knowledge workers in an environment of continuous change.

\section{Business Managers}

Information technology has impacted upon all levels of management in two ways. First, the increasing use of IT by subordinates (particularly knowledge workers) may require changes in management practices (McInerney, 1999). Second, the use of IT by senior and middle managers has affected their working relationships. These changes are of particular significance for the IS professional because IT-related change at these levels can be highly political, often involving structural change within the organisation, and the conventional resort to line managers or project champions is not feasible. For this reason, it is instructive to consider the impacts of IT on managers in the light of organisational structures and power relations.

Over the past two decades, senior managers have sometimes regarded middle managers as obstacles between their plans and the implementation of these plans at the organisation's front-line (Brubakk and Wilkinson, 1996). Senior management perceptions of this sort are likely to have contributed to the downsizing of middle management, which was in evidence throughout much of the 1980s and 1990s (Appelbaum 
and Santiago, 1997). During the same period, however, the pressure for organisations to change have increased and the middle manager has, consequently, been seen by some as acquiring a more important role (Dixon, 1995a; Dixon, 1995b; Dopson and Stewart 1989). One of the reasons cited for this changing role is that middle managers play a significant part in processing information and communicating its implications (often in a biased way) in order to influence key stakeholders (Mintzberg, 1975). These activities are critical to effecting cultural change (Ogbonna, 1993). In this regard, it can be expected that the interaction between middle management and information and communication technologies is a complex and difficult challenge for the IS professional.

Although information technology has long been postulated as a threat to middle management, owing to its potential for facilitating downsizing (Leavitt and Whisler, 1958), recent research suggests that the impacts of IT on middle management are far from uniform. There are strong indications that IT tends to be used to support the downsizing of middle management in companies with highly centralised decision making but tends to be associated with the growth of middle management in decentralised organisations (Pinsonneault and Kraemer, 1993; Pinsonneault and Kraemer, 1997). These findings are not inconsistent with the view that middle managers are sometimes seen as an obstacle to senior management goals. In centralised organisations, it appears, middle management may make more use of codified information to make formulaic decisions. Such managers are more likely to be candidates for replacement by computer systems that provide more senior managers with direct control. Where middle manager activity cannot be replaced, there may often be opportunities to delegate these tasks to the growing body of knowledge workers at lower levels in the organisation. In contrast, decentralised organisations are more likely to contain middle managers who use many informal information sources and make judgements in a more 'creative' way. Such managers may make greater use of rich technologies, such as those studied by knowledge management researchers. In this case, middle managers may be seen as adding value by coordinating and facilitating knowledge worker activity.

Whilst much further research is required to explain the impact of IT on management relationships, the key point to note is that different types of management arrangements impact upon the role of the IS professional in dealing with middle and senior management. In some organisations, the IS professional may be expected to work with senior management in eroding the functions of middle managers and redistributing work to knowledge workers. In other organisations, the middle managers may be responsible for realising senior management's goals by developing a range of IS and IT facilities for their knowledge workers. In this case, the IS professional will have a more cooperative relationship with middle management.

\section{Government}

Governments have two broad areas of responsibility in terms of developing a knowledge society: (a) developing a sustainable socio-economic framework for the private sector; and (b) restructuring the public sector to meet the demands of a knowledge society. Whilst these tasks impact upon all aspects of society, the developments of most direct concern to the IS community are:

- the development of information and communication technology infrastructure;

- IS and IT related legislation and regulation;

- employment policies related to IS skills; and

- on-line government.

In all developed, and many developing, nations, policies and actions can be identified in all of these areas and their impacts assessed in terms of economic performance and social welfare. The United Kingdom is used as a case study to illustrate the significance and complexity of these issues.

\section{ICT Infrastructure}

Over the past 50 years, economic growth and job creation have been major priorities for most nations (Mitchell, 1999). The significance of information technologies in addressing these aims is illustrated by various economic analyses. In the US, for example, information and communication technologies (ICTs) were responsible for 35\% of real economic growth between 1995 and 1998 (US Department of Commerce, 1999). In addition to the traditional uses of information technologies, e-commerce is expected to account for $4 \%$ of UK Gross Domestic Product by 2002 (Performance and Innovation Unit, 1999). The development of a supportive ICT infrastructure, therefore, can be regarded as an essential enabler of business activity in the knowledge society. Recent policies and actions relating to the UK's ICT infrastructure include:

- Actions by the telecommunications regulator (OFTEL) to increase the provision of high-bandwidth services by reducing the monopoly power of British Telecom.

- The auctioning of radio spectrum for the provision of third generation mobile services (Radiocommunications Agency, 1999); and

- The proposed auctioning of radio spectrum for the provision of broadband (2-5 Mbit/s) fixed wireless access to provide 'last mile' telecommunications services (Radiocommunications Agency, 2000). 
These three actions by government agencies will have major impacts on the development of the 'information superhighway' and, consequently, upon British industry's capability for competing in the global knowledge economy. The sales of third generation $(3 \mathrm{G})$ mobile licences, for example, raised $£ 22.5$ billion for the British government. Clearly, this money will be of social benefit insofar as it will contribute to funding public expenditure. The auctioning of licences did result, however, in the current mobile phone operators paying much more for the licences than they expected. This is likely to be because not having a licence would present a major threat to their future business performance (Hunter, 2000). The operators now face a major challenge in developing a business model that will enable them to profit from the provision of $3 \mathrm{G}$ mobile services. Some industry analysts have suggested that paying for the licences could reduce the resources available for infrastructure development (Cane et al., 2000). This may slow down the introduction of $3 \mathrm{G}$ services to British businesses and consumers, particularly in relation to countries where licences were sold (not auctioned) at much lower prices (for example, Denmark, France, Italy, Spain and Sweden). The cost of $3 \mathrm{G}$ to mobile operators may be further increased by a range of problems that could lead to $3 \mathrm{G}$ services not becoming widespread until 2005; three years later than envisaged (Dunn and LaPedus, 2000). Such costs will eventually be passed on to the customer, possibly resulting in British businesses and consumers paying more and receiving lower quality mobile services than in other European countries. It will be towards the end of the decade before a thorough assessment of the social impacts of the government's licensing decisions can be made. IS research in this area could provide valuable insights to inform future government policy as well as informing businesses about the strategic implications of technology policy changes.

\section{IS/IT Related Legislation and Regulation}

The IS profession has been affected by a range of specific legislation for many years. In England, this includes the Data Protection Act 1984, the Copyright (Computer Software)

\begin{tabular}{|l||}
\hline \multicolumn{2}{|l|}{ Proposed Leglisation } \\
\hline$\quad$ Freedom of Information Bill \\
\hline Active Legislation \\
$>\quad$ Regulation of Investigatory Powers Act 2000 \\
$>\quad$ Electronic Communications Act 2000 \\
$>\quad$ Telecommunications (Data Protection and Privacy) \\
$\quad$ Regulations 1999 \\
$>\quad$ Data Protection Act 1998 \\
$>\quad$ Wireless Telegraphy Act 1998 \\
Table 2 - Recent and proposed English legislation \\
relating to information and communication technolo- \\
gies \\
\hline
\end{tabular}

Amendment Act 1985, the Computer Misuse Act 1990 and the Data Protection Act 1998. As IT converges with telecommunications, the long history of telecommunications law must also be considered (in the UK, this dates back at least to the Wireless Telegraphy Act 1949, which serves as the basis for the 1998 Act). The rapid growth of e-commerce now requires the IS professional to be aware of the full range of business law and to monitor the rapid development of national and international e-commerce legislation. Table 2 summarises legislation introduced or proposed since 1998.

As these recent developments illustrate, legislation will lead to significant changes to the working practices of IS professionals. Whilst legal issues per se will remain the responsibility of IT lawyers, the IS professional will ultimately be responsible for implementing systems and, consequently, must work closely with legal advisers to ensure that new and existing systems comply with developing legislation. As illustrated earlier, the convergence of information and communication technologies also requires vigilance with respect to government regulation.

Organisational competencies for monitoring and addressing policy and legislative issues, however, presently seem to be lacking (Jarvenpaa and Tiller, 1999).

Considering government regulation, the convergence of information and communication technologies leads to the convergence of previously distinct types of regulation (Blackman 1998). As shown in Table 3, the IS professional has been relatively untouched by regulation. The convergence of personal communications, broadcasting, publishing and data interchange, however, means that regulation will need to be revised to account for the new possibilities that the Internet enables. Thus, the IS professional will increasingly be required to understand and operate within a complex of rapidly changing regulation. A key challenge for governments is to ensure that regulatory developments satisfy the basic principles underpinning all regulation: ensuring that markets are efficient, innovative and competitive; and protecting the public interest. The IS community's expertise is potentially valuable in this regard.

\begin{tabular}{|l|c|c|}
\hline & \multicolumn{2}{|c|}{ Focus of Regulation } \\
\hline & $\begin{array}{c}\text { Means of } \\
\text { Transmission }\end{array}$ & $\begin{array}{c}\text { Transmitted } \\
\text { Content }\end{array}$ \\
\hline Telecommunications & $\checkmark$ & $\boldsymbol{x}$ \\
\hline $\begin{array}{l}\text { Audio-Visual Broad- } \\
\text { casting }\end{array}$ & $\boldsymbol{x}$ & $\checkmark$ \\
\hline Publishing & $\boldsymbol{x}$ & $\checkmark$ \\
\hline Computing & $\boldsymbol{x}$ & $\boldsymbol{x}$ \\
\hline
\end{tabular}




\section{IT Skills and Employment Policy}

The British Government has published several documents regarding the knowledge economy, each of which recognises the need to develop new skills. These documents recognise the importance of skills such as entrepreneurship, combining technical and business expertise, IT and information skills and high quality management as critical to the success of a knowledge driven economy. Actions to increase the skills levels in these areas include: (a) increasing university-industry collaboration; (b) encouraging interaction between businesses and secondary schools; (c) achieving greater coherence of vocational training programmes; and (d) establishing new government bodies to coordinate management and enterprise education (Department for Trade and Industry, 1998; ITCE Skills Strategy Group, 1999). As discussion elsewhere in this paper indicates, the focus of government action has primarily been increased economic performance and job creation. Although there has been some discussion of social exclusion, the long-term social implications of such socio-economic restructuring receive relatively little attention. The IS community can play a valuable role both in furthering understanding of these social impacts and in addressing skills issues through the provision of IS and IT education and training. To do this effectively, however, the IS community and other stakeholders require an effective means for sharing their knowledge and coordinating their activity.

\section{On-Line Government}

Over the past few years, the Government has made numerous commitments to providing public services over the Internet. The claimed benefits of on-line government are identified in the Government.Direct Green Paper (Central Information Technology Unit, 1996) as:

- greater accessibility;

- greater convenience;

- increased ease of use;

- more responsive service provision; and

- reduced cost of service delivery.

According to government policy, the main way of achieving these aims is to use the Internet to provide self-service facilities for tax collection, granting licences, paying grants and a range of other necessary tasks. It seems plausible to expect an increase in self-service to result in lower service delivery costs and cross-departmental systems integration to increase convenience (e.g, a change of address form will no longer need to be provided to all government departments). Consideration of the broad social picture, however, suggests that trade-offs will need to be made between the objectives listed above. Internet service provision, for example, does not automatically in- crease the accessibility of services. It is possible, for example, that cost savings can only be made by reducing conventional modes of access to services, such as local government offices. This may make services less accessible to some citizens, such as older people who are less likely to be IT literate and more likely to find travelling difficult. Similarly, increased ease of use presupposes that on-line alternatives to existing paper forms will be easier for the citizen to complete. This is not necessarily the case, with ease of use being contingent upon IT literacy, the effective design of user interfaces and business processes being carefully redesigned to account for all modes of access (and variations within and between them). A great deal of research into service provision, both in the public and private sectors, is required to provide a thorough and systematic analysis of technical, business and social impacts of ITbased service provision. Without such research, the long-term societal impacts of 'on-line government' policies cannot be fully appreciated and managed, nor can the IS professional's role in implementing these policies be developed. Such research can be done most effectively with the involvement of government, technology vendors, service providers and researchers with expertise in social and organisational impacts of information technologies. As in the case of skills issues, coordination and communication mechanisms are required to facilitate such investigations.

\section{The Information Poor}

A major social concern about the emerging knowledge society is the extent to which changes will exaggerate or reduce existing inequalities between and within countries. These concerns are reflected here by identifying those who may be disadvantaged as a distinct (but highly diverse) stakeholder group. To make this stakeholder group meaningful as a basis for discussion, it is necessary to establish who is likely to lose out as a direct result of a lack of information. This must be achieved with concern for cultural biases, such as assuming that IT adoption by Western professionals is a touchstone for social progress. For this reason, two perspectives on information poverty are taken. First, a global perspective considers the implications of a knowledge society change in global terms. Second, social exclusion arising from poor information access is considered at the national and sub-national levels in emerging knowledge economies.

\section{Global Perspective}

When considering the potential value of information and IT at the global level, two factors are of most concern:

- the ability to produce and use information; and

- the benefits of information use. 


\begin{tabular}{|c|c|c|c|c|c|c|c|c|c|}
\hline & $\begin{array}{l}\text { GNP per } \\
\text { capita (\$) } \\
\text { Avg. Annual } \\
\text { Growth (\%) } \\
\end{array}$ & $\begin{array}{l}\text { Access to } \\
\text { Safe Water } \\
\text { (\% of popula- } \\
\text { tion) }\end{array}$ & $\begin{array}{l}\text { Electric Power } \\
\text { (Consumption } \\
\text { per capita in } \\
\text { kwh) }\end{array}$ & $\begin{array}{l}\text { Industry Activity } \\
(\% \text { male, \%female })\end{array}$ & $\begin{array}{l}\text { Illiteracy Rate } \\
(\% \text { male \%fe- } \\
\text { male })\end{array}$ & $\begin{array}{l}\text { Newspapers } \\
\text { (per } 1000 \\
\text { people) }\end{array}$ & $\begin{array}{l}\text { Television } \\
\text { (sets per } \\
1000 \text { peo- } \\
\text { ple) }\end{array}$ & $\begin{array}{l}\text { Telephone } \\
\text { Lines per } \\
1000 \\
\text { people }\end{array}$ & $\begin{array}{l}\text { Internet } \\
\text { hosts (per } \\
10,000 \\
\text { people) }\end{array}$ \\
\hline Benin & $\begin{array}{l}380 \\
1.9\end{array}$ & 50 & 43 & $\begin{array}{ll}\text { Agriculture } & 66,69 \\
\text { Industry } & 10,4 \\
\text { Services } & 24, \\
27^{1} & \end{array}$ & $\begin{array}{ll}\text { Adult } & 46, \\
77 & \\
\text { Youth } & 25, \\
65 & \\
\end{array}$ & 2 & 10 & 7 & 0.04 \\
\hline Cambodia & $\begin{array}{l}260 \\
-2.3\end{array}$ & 13 & & $\begin{array}{ll}\text { Agriculture } & 71,79 \\
\text { Industry } & 6,3 \\
\text { Services } & 23,18\end{array}$ & $\begin{array}{ll}\text { Adult } & 43, \\
80 & \\
\text { Youth } & 26, \\
61 & \\
\end{array}$ & 2 & 123 & 2 & 0.12 \\
\hline Eritrea & $\begin{array}{l}200 \\
-6.7\end{array}$ & 7 & & $\begin{array}{ll}\text { Agriculture } & 79,88 \\
\text { Industry } & 7,2 \\
\text { Services } & 14,11\end{array}$ & \begin{tabular}{|ll} 
Adult & 34, \\
62 & \\
Youth & 21, \\
41 & \\
\end{tabular} & & 14 & 7 & 0.01 \\
\hline India & $\begin{array}{l}440 \\
4.3\end{array}$ & 81 & 363 & $\begin{array}{ll}\text { Agriculture } & 63,83 \\
\text { Industry } & 15,9 \\
\text { Services } & 22,8\end{array}$ & \begin{tabular}{|ll} 
Adult & 33, \\
57 & \\
Youth & 22, \\
37 & \\
\end{tabular} & & 69 & 22 & 0.18 \\
\hline Australia & $\begin{array}{l}20640 \\
4.4\end{array}$ & 99 & 8307 & $\begin{array}{ll}\text { Agriculture } & 6,4 \\
\text { Industry } & 31,11 \\
\text { Services } & 63,85 \\
\end{array}$ & & 293 & 639 & 512 & 477.85 \\
\hline Greece & $\begin{array}{l}11740 \\
3.1\end{array}$ & & 3493 & $\begin{array}{ll}\text { Agriculture } & 18,23 \\
\text { Industry } & 28,13 \\
\text { Services } & 54,64 \\
\end{array}$ & \begin{tabular}{|ll} 
Adult & 2,5 \\
Youth & 0,0
\end{tabular} & 153 & 466 & 522 & 59.57 \\
\hline France & $\begin{array}{l}24210 \\
2.8\end{array}$ & 100 & 6060 & $\begin{array}{ll}\text { Agriculture } & 6,4 \\
\text { Industry } & 37,15 \\
\text { Services } & 57,81\end{array}$ & & 218 & 601 & 570 & 110.64 \\
\hline UK & $\begin{array}{l}21410 \\
2.0\end{array}$ & 100 & 5241 & $\begin{array}{ll}\text { Agriculture } & 3,1 \\
\text { Industry } & 38,13 \\
\text { Services } & 59,86\end{array}$ & & 329 & 645 & 557 & 270.60 \\
\hline USA & $\begin{array}{l}29240 \\
1.5\end{array}$ & & 11822 & $\begin{array}{ll}\text { Agriculture } & 4,2 \\
\text { Industry } & 34,13 \\
\text { Services } & 63,85\end{array}$ & & 215 & 847 & 661 & 1508.77 \\
\hline
\end{tabular}

A comparison of basic socio-economic indicators for poor and wealthy nations provides a broad overview of the issues faced (Table 4). For the poorest countries, modern ICTs are prohibitively expensive - a single PC costing a multiple of the GNP per capita (column 2). Basic infrastructure is also inadequate for widespread technology adoption, as illustrated by the lack of safe water suppliers, electric power and telephone lines (columns 3, 4 and 9). Even were information readily accessible in these countries, the ability to exploit it is limited by high rates of illiteracy (column 6) and the relatively low familiarity with information sources such as newspapers, television and the Internet (columns 7, 8 and 10). The potential benefits of utilising information and IT are also quite low, given the economic structure of poor nations. The vast majority of workers are employed in low-technology agriculture and industry (column 5), suggesting that working practices stand to benefit little from increased access to information. Social benefits may arise but the most immediate gains in this respect are from more basic forms of infrastructure (Maddy, 2000). It is important to note the tendency to conflate information and knowledge; poorer countries stand to gain 176 mation and knowledge; poorer countries stand to gain most from knowledge about more effective ways of doing things, which is not provided by the majority of (especially electronic) information sources (Burkett, 2000).

One source of potential economic benefit from ICTs is the possibility of developing knowledge-based services for export to developed countries. India perhaps, best illustrates the benefits of such a strategy, which has been successful in both software development and the provision of customer support services. This economic development is one of many that have led to India having a higher rate of economic growth than most other developing countries. Whilst economically beneficial, it should be noted that India has succeeded because it has some quite sophisticated urban areas, which have quite good infrastructure and education provision. It is primarily these urban areas that will benefit from knowledge work and, depending upon government policy, this may lead to either a widening of the gap between rich and poor or to a general improvement in welfare for Indian citizens. 
Going beyond basic indicators, such as those in Table 4, geography, culture and political regime will continue to play major roles in determining individual welfare. This is illustrated by comparing nations with similar economic performances. Viet Nam, for example, has a similar GNP per capita to Guinea but has an average life expectancy almost twenty years greater and a literacy rate of over $90 \%$ compared with less than $40 \%$ in Guinea (United Nations, 2000). Clearly, these countries are positioned quite differently in terms of their abilities to enter into, and benefit from, a global knowledge economy. Attempts by China to censor Internet traffic also illustrate the potentially enormous impacts of political regimes on the ability of citizens to participate in global changes. This is not to suggest that globalisation per se is desirable, however, as illustrated by the potential threat to national identity of using English as a global language and the increasingly pervasive impact of North American culture in other developed countries.

\section{Local Perspective}

As indicated above, individuals in the poorest countries stand to gain least from increased quantities of information because their present circumstances present them with few opportunities to change their lifestyles or ways of working. In emerging knowledge economies, however, many individuals could improve their wellbeing by making better informed decisions but

\section{Intellectual Capabilities}

1. Engage in sustained reasoning

2. Manage complexity

3. Test a solution

4. Manage problems in faulty solutions

5. Organise and navigate information structures and evaluate information

6. Anticipate changing technologies

7. Think about information technology abstractly

Information Technology Concepts

1. Computers

2. Information systems

3. Networks

4. Information organisation

5. Algorithmic thinking and programming

6. Societal impact of information and information technology

\section{Information Technology Skills}

1. Setting up a personal computer

2. Using a word processor to create a text document

3. Using a computer to communicate with others

4. Using instructional material to learn how to use new applications or features

Table 5 - US National Research Council's broad description of IT literacy (Adapted from Lin 2000) are unable to do so. Understanding this kind of information poverty requires consideration of three issues:

- the kinds of needs that can be satisfied by increased access to information and ICTs

- the skills and resources required to access and make use of information and ICTs

- the socio-economic factors that enable and constrain the actions of the information poor

A number of personal and employment benefits of access to information and ICTs are identified by Lin (2000). Some examples of these are shown in Table 5. It is clear from these examples that lack of information and/or ICT access can lead to significant loss of quality of life in a knowledge-driven society.

Considering what kinds of skills are required, the US National Research Council has argued that many definitions of IT literacy are too narrow and the provision of ICT skills has, consequently, often failed to enable individuals to benefit from improved access to information (Lin, 2000). They suggest that three broad skills areas need to be addressed (Table 5). It is important to recognise that these skills are interdependent enablers, so that a deficiency in any one can lead to a significant loss of access to, or ability to use, information to inform decisions.

Finally, there is evidence to suggest that some individuals with the capacity to improve their wellbeing are unable to do so owing to socio-economic constraints. Three broad issues seem to be particularly significant. First, ICTs have been mostly been designed for middle class professionals (for example, the PC and mobile phone). This may confer an advantage to these users over other social groups because the technologies better accommodate their lifestyles and needs. Market mechanisms may not lead to the development of products to address the needs of poorer social groups because they are regarded as less profitable. Second, those with poor access to ICTs often have poor access to other resources and infrastructure. Even with access to ICTs, many individuals may not be able to act on the information they acquire. Ebusiness is a particular concern because of its potential to reduce the availability of physical facilities, such as shops and offices, particularly in poor and rural areas. In an ageing population, a sparse distribution of physical resources may itself have a negative impact on quality of life. Third, the knowledge economy paradigm implicitly assumes the acceptance of intellectual meritocracy as a driver of socio-economic progress. Such a value system necessarily produces, and discriminates against, groups that are information poor, unless specific intervention is made on a continuing basis. Thus, traditional concepts of social welfare may need to be adapted to 
reflect the differences between industrial and knowledge economies.

\section{IS Academics}

As a stakeholder group, IS academics perform two core activities, teaching and research, which are the primary concerns of this paper. A third issue of concern is the resourcing of the IS academic community, particularly its intellectual assets - in other words, academic pay and promotion. These issues are considered in turn.

\section{Information Systems Education}

In terms of IS education, the above stakeholder analysis identifies the following broad concerns:

- the mechanism by which curricula are constructed and the values underlying a given curriculum;

- the role of IS curricula in the broader context of IS professional development; and

- the relevance of IS curricula to the needs of diverse stakeholder groups.

At present, the mechanisms guiding IS curriculum development are twofold: (a) compliance with internal university procedures; and (b) the publication of curricula by members of the IS academic community for voluntary adoption. Whilst internal university procedures provide some general quality assurance, they cannot contribute to the development of IS specific notions of quality and relevance. Thus, the only mechanism for creating common standards and for sharing educational best practice is the publication of documents within the IS community. In comparison with other professions, this mechanism is weak and, as already noted, leads to the following problems:

- lack of standardisation creates uncertainty for employers regarding the knowledge and skills to be expected of IS graduates;

- the absence of formal control by professional bodies over IS curriculum development leaves industry expectations of IS graduates unmanaged and limits the ability of industry to communicate its needs;

- lack of standardisation of curricula across universities increases the effort required of IS academics in developing basic curricular resources, reducing the time and resources available for incorporating new technologies; and

- lack of standardisation across universities reduces the potential for transferring best practice in terms of IS pedagogy.
These factors suggest that efforts to establish formal curriculum development bodies involving industry representation would benefit four stakeholder groups: IS academics, IS students, IS professionals and business managers. Such a mechanism is also be likely to receive the support of governments because it would facilitate teaching quality assurance, increase resource efficiency and increase the economic value of IS graduates. There are, however, some significant obstacles to the development of IS curricula by academic-industry bodies, with the most significant being the acute shortage of IS professionals and the limited ability of many small IS groups/departments to implement a standard curriculum. The IS skills shortage also represents a major obstacle to establishing support for IS professional development.

It is clear that curriculum development and implementation faces a unique set of demands, many of which compete. As already noted, there is considerable pressure from several stakeholder groups for the provision of relevant skills. Particularly in the case of technical skills, teaching materials require at least annual revision. The 'product lifecycle' for a degree programme, however, is around five years from curriculum design to the graduation of students from a three year course. This tension is currently resolved by articulating the curriculum in terms of the educational rather than training elements of university teaching in order to ensure long-term relevance, with reference to 'up-to-date' or 'state-of-the-art' skills. This approach can help to ensure that IS curricula deliver fundamental analytical and problem solving skills but can draw criticism from stakeholders expecting practical relevance. These criticisms are not easily countered because resources must be committed to curriculum delivery, leaving teachers with little time and few resources to learn about new technologies and use them to facilitate curriculum delivery.

IS programmes can be placed on a continuum between the demand for long-term educational relevance and the demands for short-term industry relevance, with there being something of a trade-off between the two. The location of a programme on this continuum will largely be determined by the type of programme and the kind of institution delivering it. MBAs, for example, must be more industry relevant owing to the profiles of the student body and fee payers. A bachelors programme, however, will typically be more academic, providing more development of analytical and problem solving skills. The location of an IS programme in a business school or computing department also has a significant effect on its character, particularly in terms of the relative emphasis of interpersonal and technical skills.

The diversity of IS programmes has both advantages and disadvantages for different stakeholders. For IS practitioners, diversity introduces considerable uncertainty into the em- 
ployment process. Whereas other professions, such as medicine, engineering and law ensure that graduates possess certain knowledge and skills regardless of their place of study, this is not the case with IS. One of the main reasons for this is that IS academics undertake curriculum development with much more autonomy than other educators. In the cases of medicine and engineering, for example, curricula are largely developed by professional bodies, with academics having very little freedom to distinguish their teaching from that in other institutions. This high level of standardisation, whilst reducing the student's ability to differentiate him- or herself in the job market, provides employers with a guaranteed minimum level of professional competence, which employers and their representatives have helped to specify. IS employers have no such influence, which may help to explain their dissatisfaction with IS education. Moreover, where employers do communicate their needs to IS academics, they do so with less experience and understanding of curriculum development and implementation because there is no official dialogue between industry and academia (note that professional bodies are not represented in Figure 1 for this reason). The lack of management of practitioner expectations of IS educators is, perhaps, leading to their deficiencies being exaggerated. The lack of standardisation also means that IS educators must work harder to construct course materials because best practice cannot be shared easily and textbooks cannot be guaranteed to correspond with the syllabus being delivered. Thus, curriculum development time is more likely to be spent duplicating similar teaching materials in many institutions, leaving less time for updating skills and awareness of industry best practice. It should be noted, however, that many professions, such as medicine, are increasing the number of optional courses offered in recognition of the fact that relevant content cannot be delivered in the time scale of a degree programme. Whilst study options increase variation in student education, there remains a common core in all professional programmes and the content of optional courses is still agreed through formal mechanisms.

The need to consider IS education in the wider context of professional development was indicated by several stakeholder concerns, including: (a) the limited capacity for providing essential skills training via IS degree programmes; (b) the increasing dependence of businesses and society on IS professionals; and (c) the growing evidence of major social impacts of 'technology decisions.' Nevertheless, neither qualification nor professional accreditation is required of IS practitioners. Given the current skills shortage, it seems unlikely that professional standards can readily be introduced because they would further restrict the short-term supply of entrants into the IS workforce. It must be recognised, however, that much of the growth in demand for IS practitioners stems from the use of computer-based IS for the strategic and key operational activities of both businesses and government. In other words, at a time when the criticality of information systems is increasing, it is plausible to suggest that there is a decline in the level of professionalism of the IS workforce as a whole. An interesting observation in this regard is that the failure to establish a clear notion of IS professionalism blurs the distinctions between knowledge worker, IS professional and the business manager. It is evident in the stakeholder analysis that the IS professional's role is continually expanding to cover many aspects of business and to support ever more sophisticated knowledge workers. There has been little recognition, however, of the need to remove skills from the IS professional's portfolio when the performance of computerand information-based tasks becomes the responsibility of managers or users. It has been recognised that business managers and senior executives, in particular, often have very low levels of technology awareness and it is conceivable that some of the pressure on IS professionals would be alleviated if nonIS professionals were less able to abdicate their responsibility for technical decisions. Communicating a clearer definition of the IS profession to other professionals would contribute to establishing professional boundaries and could help to establish the levels of IS and IT knowledge required by knowledge workers and managers to fulfil their new roles in the knowledge society.

Curriculum relevance is one of the more difficult issues to apprehend because 'relevance' has quite different meanings for the different stakeholder groups and at different levels of analysis. Figure 2 illustrates how current relationships between stakeholder groups in industry result in IS academics being faced by disparate notions of relevance (in addition to the demands to provide a sound academic education). With existing mechanisms for curriculum development, there is limited scope for reconciling these needs through dialogue and negotiation and no means by which stakeholder expectations can be managed. Some progress has been made through the consultation of industry in developing IS curricula for voluntary adoption, although, as already noted, such a mechanism is weak in comparison with those of other professions and given the substantial pressures facing IS academics and practitioners.

The notion of curriculum development appears yet more problematic when it is recognised that the IS/IT profession can be segmented according to the needs of businesses and by geography. The broad range of activities that IS professionals might perform is captured by the British Computer Society's IS skills framework and ranges from hardware installation through to strategic planning and marketing. At present, the lack of a career structure identifying skills with particular roles causes confusion for both employers and those in the labour market. It also complicates the task of identifying areas 


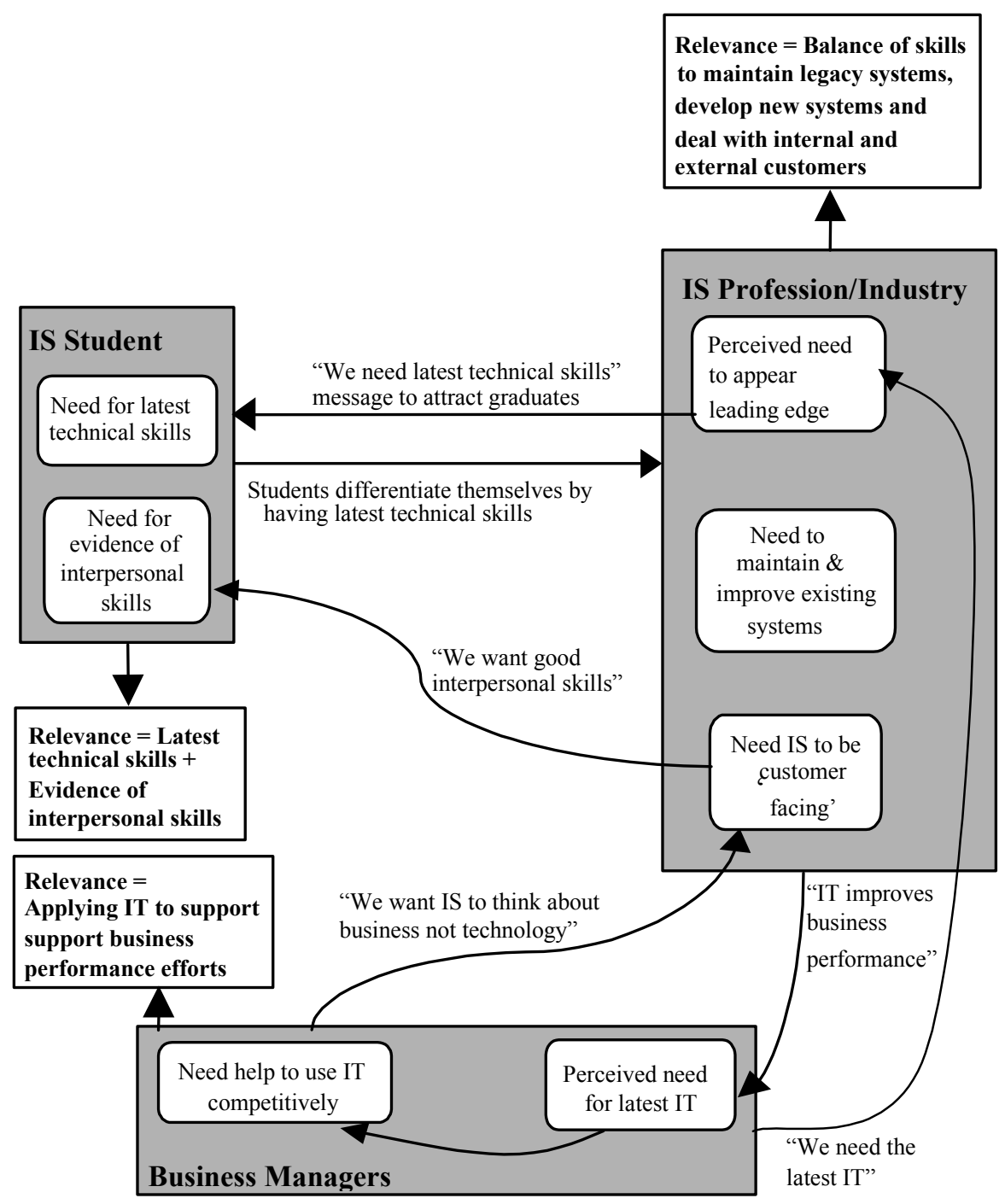

Figure 2 - An illustration of the different conceptions of the relevance of IS education

of particularly acute skills shortage and targetting education and training at particular vocational roles. Segmentation of the IS/IT labour market reveals that skills demands do vary by geography and benefits can accrue for employers and employees when educational programmes are tailored to local needs (Lee et al., 1996). It should be recognised, however, that there are risks associated with responding to such regional variation for both universities and students.

\section{IS Research}

Looking at IS academics as knowledge producers, both technical and managerial researchers are relatively successful in satisfying the demands of government and industry for relevance and capitalisation. For this reason, many IS researchers have been successful in acquiring industry funding. Success in these terms raises three concerns for the IS research community:

- the need to differentiate academic research from the work of corporate IS research and analysis;

- a limited ability to conduct research into the social impacts of IS/IT, particularly over the longer term; and

- difficulties in establishing a language for academic discourse about information systems.

These three problems are interrelated and concern the extent to which IS can pursue the road towards knowledge capitalisation and retain core academic values. IS faces the additional challenge of not having existed as a discipline prior to the introduction of massification and capitalisation policies. 
The need to differentiate academic IS research from corporate $R \& D$ and industry analysis essentially concerns values such as academic rigour and impartiality. Whilst rigour is not necessarily undermined by industry funding (and is likely to be a desirable quality for the research sponsors), it is important to recognise that the increasing rate of change in industry creates pressure for research that delivers results more quickly. This limits opportunities to conduct longitudinal research of significant academic value because the legitimate claims of sponsors to research benefits must be addressed. The extent to which this problem at all undermines research quality is questionable. Publicly funded research must also keep pace with industry change in order to retain its relevance. Thus, it may be the case that rapidly changing social and organisational phenomena necessitate research designs with short-term objectives (possibly tied-in to a longer-term goal). Moreover, industry sponsored research often provides an advantage in terms of increased access to the research subject. The main challenge for IS academics is to develop models of research activity that are suited to the changing subject of study. A particular challenge is ensuring that multiple qualitative research studies can be systematically compared and valid generalisations established.

Impartiality is a difficult issue to address because, as already noted, sponsors have a legitimate claim to benefits from research. Two factors mitigate concerns about impartiality (although not completely): (a) practitioner and academic objectives can sometimes run in parallel; and (b) projects can be funded by multiple sponsors, reducing the overall influence of a single company's interests on the direction of research. There remain, however, some limitations, particularly in terms of addressing the social aspects of research problems. Such issues are not only of limited concern to industry sponsors but occasionally may be in opposition to commercial goals. This does not imply that industry funded research is of limited academic value but strongly suggests that some IS research issues require public sector recognition and funding.

An ongoing concern, at least in the UK, is that IS research has not received sufficient public recognition, either in terms of its social significance or in terms of financial support (Stowell, 2000). Two possible reasons for this are: (a) the relative youth of the discipline; and (b) the push towards the capitalisation of publicly funded research. The first factor is unlikely to be significant, given that related disciplines, such as computer science, and new disciplines, such as biotechnology, have experienced success. The pressure for capitalisation, however, may be significant for two reasons. First, where industry has been willing to fund IS research in its entirety, government has no motivation or justification for using public money. Second, where IS funding does not attract commercial funds, it is likely to be because the research does not offer economic advantage, even though it may address important issues of public interest (Polster 2000). Such research is less consonant with the new aims of public research funding and, hence, is more likely to experience problems in attracting public funds.

The third concern for IS research is its language. The IS lexicon has become highly complicated owing to two factors. First, drawing upon multiple reference disciplines has introduced terminology from other areas of research. This breadth of IS vocabulary seems to have occurred at the expense of precision in the description and analysis of IS phenomena. The lack of substantive IS theory means that terminology is often used in different ways and it becomes difficult to demonstrate that IS has progressed its understanding, either by building upon research in reference disciplines or by synthesising research from multiple disciplines. The identity and validity of IS is further confused by the adoption of terminology from IT vendors and consultants. The use of this terminology exposes IS academics to the challenge that their 'research' is more of a commentary on recent happenings in industry than a valid development of substantive knowledge. On the other hand, the use of a narrow, specialised terminology based only upon substantive and well-corroborated theory would expose IS academics to accusations of adopting an 'ivory tower' mentality and conducting research that is not relevant to its key stakeholders.

The above factors, in combination, all closely relate to the lack of recognition of IS research in the broader sense and concerns within the IS community about the discipline's identity and integrity. As such, they must be addressed by future efforts to shape IS research. The IS academic community as a whole should, therefore, attempt to ensure that it develops the capability to balance the interests of, and pressures exerted by, different stakeholder groups. This capability must include demonstrating to public funding bodies the long-term implications of different balances of particular/general, private/public and pure/applied research and their impacts on the wellbeing of all stakeholder groups.

\section{IS Academic Pay and Promotion}

The third issue relating to IS academia to be considered here is pay and promotion. In this regard, it is instructive to consider the general state of the market for IS academics. The employment situation in IS has changed rapidly over the past decade, going from oversupply in 1991 to acute shortage by 1998 (Freeman et al., 2000). The shortage of IS academics is envisaged to continue, or worsen, well into the present decade, owing to a number of factors, including: 
- Industry developments, such as e-business, have led to increased demands for IS courses, which, in turn, have increased demands for IS teaching faculty.

- Most new IS academics are recent IS PhD graduates and the number of IS PhD students has not increased for several years, at least in the USA (Freeman et al 2000).

- The IS skills shortage in industry is attracting some academics and PhDs away from academic careers. This trend may be increased by the increasing disparity between the salaries of IS academics and practitioners.

- Emphasis on academic research may be offputting for IS practitioners considering a move into academia. Experienced practitioners are likely to be most valuable in terms of (and most interested in) teaching, yet teaching skills are undervalued by some forms of university assessment.

It should be noted that both the demand for and supply of IS academics seems to be affected by industry changes. Downsizing in the late 1980s and early 1990s, for example, had a major impact on the demand for IS graduates and, consequently, affected demand for IS educators (Couger, 1993). There has been no clear evidence, however, that downsizing led to a surplus of IS practitioners who could bring their skills into IS academia. It remains to be seen how major industry changes, such as e-business and the strategic use of IT, will affect demand for IS programmes and what effect this will have on the supply and demand of IS academics. It should be noted, however, that governments in developed economies are placing a significant emphasis on IT and e-business as major sources of structural change and economic growth. This suggests that demand for IS programmes is likely to grow at least over the medium term.

\section{Conclusions}

Information systems and information technology are having increasingly significant impacts on individuals, organisations and societies. The IS academic community is tasked with understanding and explaining these impacts, using this understanding to reconceptualise IS and to develop teaching and research programmes that reflect the ever-changing roles of information and IT in society. In so doing, it must retain a sensitivity towards all stakeholder groups and how their needs are evolving. This implies continuous change for the IS academic community, which, if unmanaged, may pose a threat to the discipline as a whole. Throughout this paper, areas where IS academics could act to change its relationships with other stakeholders have been identified. These 'policy level' actions are summarised here.

In terms of their educational function, IS academics need to consider their role in the wider context of social and political changes. These include the delivery of generic IS/IT skills

182 through all levels and types of education, the growth in higher education and the moves towards lifelong learning and frequent retraining throughout the career. These changes affect what IS academics are required to teach and what teaching methods are likely to be effective. They also indicate that universities will be only one source of IS education and training and that universities may need to be more innovative in their educational provision. In this changing context, education and training institutions from both the public and private sectors will need to cooperate or compete to satisfy the needs of industry as the educational landscape is redefined by attempts to realise the knowledge society paradigm. Success in this regard will require a sophisticated understanding of 'relevance' as applied to IS education by each stakeholder group. As IS/IT continues to grow in economic and social significance, stakeholders in business and education will also need to develop more effective institutional mechanisms for assuring the quality of education and training, and the quality of IS educators and professionals themselves. Without such professionalisation, IS may face long-term problems of credibility and risks causing avoidable harm to individuals and organisations.

Considering IS research, a pressing concern is to examine the impacts of alternative models of university-industry collaboration to determine what they can and cannot achieve. This evidence can be used both to inform the design of IS research and to argue more convincingly for public research funding where the public interest cannot be served through commercially sponsored research. New research models will also need to be sought where the increased pace of industry change makes current approaches to research appear too inflexible and insensitive. IS research methods also need to be expanded in scope to reflect the growing impact of information and IS/IT on society, particularly as knowledge work and ecommerce grow in significance. This requires expansion upon the successful exploration of research into the organisational aspects of information systems, perhaps by drawing upon research methods already used at the economy and social group levels. Such an extension of IS research would enable the IS academic community to play a greater role in informing the significant policy developments currently taking place (Kling et al., 2000). Again, a broad range of stakeholders will need to be considered at local, national and international levels, suggesting that greater cooperation between IS researchers (both public and private) may be required. Finally, there is a need to consider how the values underlying technological and social systems serve different stakeholder groups in different ways. This kind of understanding has already been successfully undertaken at the organisational level by the IS community but further efforts are required to gain a full appreciation of the societal issues. This study of different value systems must be performed with an acute awareness of how these social 
changes are impacting upon the IS research community and the ways in which it is funding and conducting research.

The need for awareness of the relationship between the IS academic community's response to stakeholder pressures and the gradual changes in its own value system has been an overarching issue raised by the analysis in this paper. Traditionally, universities have aspired to achieve impartiality and equal concern for all members of society. For most, if not all, IS academics, these values remain central to their efforts. As a 'post-capitalisation' discipline, however, IS also prides itself in achieving a high degree of relevance of its research to the business community. As external pressures continue to emphasise the commercial value of research, these three values, which are not in themselves contradictory, become more difficult to balance, owing to the increased accountability of the IS researcher to particular stakeholder groups. This pressure has been recognised as a threat to universities generally (Gumport, 2000) but is likely to be more threatening to IS because of its lack of history as a traditional discipline and the greater competition from commercial knowledge producers. To address the range of issues and concerns raised, a number of suggestions have been offered throughout this paper. Many of them relate to the need for the IS academic community to coordinate its formal engagement with other stakeholder groups so that it can exert more pressure of its own. By doing so, IS academics may be better able to manage their present and future challenges in a more balanced way, resulting in more effective collaboration with government and industry.

\section{References}

Appelbaum, S.H., \& Santiago, V. (1997). Career development in the plateaued organization. Career Development International , 2, 1120.

Blackman, C.R. (1998). Convergence between telecommunications and other media. Telecommunications Policy, 22, 163-170.

Brubakk, B., \& Wilkinson, A. (1996). Changing roles of middle management? A case study of bank branch management. Journal of Retailing and Consumer Services, 3, 163-174.

Burkett, I. (2000). Beyond the 'information rich and poor': futures understandings of inequality in globalising informational economies. Fortunes, 32, 679-694.

Cane, A., Adams, C., \& Jowit, J. (2000). UK Mobile Bids Pass \$16bn. FT.com, Accessed 26 October 2000.

Carayannis, E.G., Alexander, J., \& Ioannidis, A. (2000). Leveraging knowledge, learning, and innovation in forming strategic government-university-industry (GUI) R\&D partnerships in the US, Germany and France. Technovation, 20, 477-488.
Cardinali, R. (1998). Viewpoint: Death of the knowledge worker. Logistics Information Management, 11, 156-159.

Central Information Technology Unit. (1996). Government.Direct: Green Paper on the Electronic Delivery of Government Services. Office of Public Service.

Couger, J. D. (1993). Essential element for viability of IS education: Improving our creativity. Journal of Information Systems Education, 5 .

Department for Trade and Industry. (1998). Our competitive future: Building the knowledge driven economy. Department for Trade and Industry.

Dixon, P. (1995a). Releasing middle management potential: part 1. Executive Development, 8, 23-25.

Dixon, P. (1995b). Releasing middle management potential: part 2. Executive Development, 8, 11-13.

Doke, E.R., \& Williams, S.R. (1999). Knowledge and skill requirements for information systems professionals: An exploratory study. Journal of Information Systems Education, 10, 10-18.

Dopson, S., \& Stewart, R. (1989). What is happening to middle management? British Journal of Management, 1, 3-16.

Dunn, D., \& LaPedus, M. (2000). Suppliers face obstacles in 3G wireless rollouts. Electronic Buyers' News.

Enders, J. (1999). Crisis? What crisis? The academic professions in the 'knowledge' society. Higher Education, 38, 71-81.

Eppler, M.J., \& Sukowski, O. (2000). Managing team knowledge: Core processes, tools and enabling factors. European Management Journal, 18, 334-341.

Etzkowitz, H. (1998). The norms of entrepreneurial science: cognitive effects of the new university-industry linkages. Research Policy, $27,823-833$.

Etzkowitz, H., Webster, A., Gebhardt, C., \& Terra, B.R.C. (2000). The future of the university and the university of the future: Evolution of ivory tower to entrepreneurial paradigm. Research Policy, 29, 313-330.

Freeman, H. (2000). Can you have a career and live with mum? The Guardian.

Freeman, L. A., Jarvenpaa, S. L., Wheeler, B. C. (2000). The supply and demand of information systems doctorates: Past, present and future. MIS Quarterly, 24.

Gumport, P.J. (2000). Academic restructuring: Organizational change and institutional imperatives. Higher Education, 39, 67-91.

Hunter, P. (2000). Game of chance. Computer Weekly, May 11. 
ITCE Skills Strategy Group. (1999). Skills for the Information Age: Final report from the Information Technology, Communications and Electronics Skills Strategy Group. Department for Education and Employment Publications.

Jarvenpaa, S.L., \& Tiller, E.H. (1999). Integrating market, technology, and policy opportunities in e-business strategy. Journal of Strategic Information Systems, 8, 235-249.

Kling, R., Crawford, H., Rosenbaum, H., Sawyer, S. \& Weisband, S. (2000). Learning from Social Informatics: Information and Communication Technologies in Human Contexts. Centre for Social Informatics, Indiana University.

Leavitt, H.H., \& Whisler, T.I. (1958). Management in the 1980's. Harvard Business Review, 41-48.

Lee, C.C., Kettinger, W.J., \& Kuilboer, J.-P. (1996). Market segmentation of IS academic programs. Journal of Information Systems Education, 8, 57-65.

Lin, H. (2000). Fluency with information technology. Government Information Quarterly, 17, 69-76.

Maddy, M. (2000). Dream deferred: The story of a high-tech entrepreneur in a low-tech world. Harvard Business Review, 56-69.

McInerney, C.R. (1999). Working in the virtual office: Providing information and knowledge to remote workers. Library and Information Science Research, 21, 69-89.

Mintzberg, H. (1975). The manager's job: folklore or fact. In H. Mintzberg (Ed.), The Strategy Process. Englewood Cliffs: PrenticeHall.

Mitchell, G.R. (1999). Global technology policies for economic growth. Technological Forecasting and Social Change, 60, 205-214.

Mumford, E., \& Ward, T.B. (1968). Computers: Planning for people. London: Batsford.

Neave, G. (2000). Diversity, differentiation and the market: The debate we never had but which we ought to have done. Higher Education Policy, 13, 7-21.

Ogbonna, E. (1993). Managing organisational culture: fantasy or reality? Human Resource Management Journal, 3, 42-54.

Performance and Innovation Unit. (1999). e-commerce@its.best.uk. Cabinet Office.

Pinsonneault, A., \& Kraemer, K.L. (1993). The impact of information technology on middle managers. MIS Quarterly, 271-292.

Pinsonneault, A., \& Kraemer, K.L. (1997). Middle management downsizing: An empirical investigation of the impact of information technology. Management Science, 43, 659-679.
Polster, C. (2000). The future of the liberal university in the era of the global knowledge grab. Higher Education, 39, 19-41.

Radiocommunications Agency. (1999). Third Generation: The Next Generation of Mobile Communications. November 1.

Radiocommunications Agency. (2000). Multimedia Access: Auction of 28GHz Broadband Fixed Wireless Access Spectrum Licences.

Rogerson, S., \& Gotterbarn, D. (1998). The ethics of software project management. In G. Collste (Ed.), Ethics and information technology. (pp. 137-154). Delhi: New Academic Publishers.

Sheridan, E. (2000). Strategies to avoid the student debt trap. The Guardian.

Stowell, F. (2000). President's Report. The UKAIS Newsletter, 5, 4-5.

Teichler, U. (1999). Research on the relationships between higher education and the world of work: Past achievements, problems and new challenges. Higher Education, 38, 169-190.

United Nations. (2000). Human Development Report 2000. United Nations.

US Department of Commerce. (1999). Emerging Digital Economy II.

Vinten, G. (2000). The business school in the new millennium. The International Journal of Educational Management, 14, 180-191.

World Bank. (2000). World Bank Development Indicators 2000. The World Bank. 